\title{
Cell signaling underlying epileptic behavior
}

\author{
Yuri Bozzi ${ }^{1}, 2 *$, Mark Dunleavy ${ }^{1,3}$ and David C. Henshall ${ }^{3}$ \\ Laboratory of Molecular Neuropathology, Centre for Integrative Biology, University of Trento, Trento, Italy \\ 2 Neuroscience Institute, National Research Council, Pisa, Italy \\ ${ }^{3}$ Department of Physiology, Royal College of Surgeons in Ireland, Dublin, Ireland
}

Edited by:

Riccardo Brambilla, San Raffaele Scientific Institute and University, Italy

\section{Reviewed by:}

Jacques Micheau, University of

Bordeaux 1, France

Gilberto Fisone, Karolinska Institutet,

Sweden

\section{*Correspondence:}

Yuri Bozzi, Laboratory of Molecular

Neuropathology, Centre for Integrative

Biology, University of Trento, Via delle

Regole 101, 38123 Mattarello, Trento,

Italy.

e-mail:bozzi@science.unitn.it
Epilepsy is a complex disease, characterized by the repeated occurrence of bursts of electrical activity (seizures) in specific brain areas. The behavioral outcome of seizure events strongly depends on the brain regions that are affected by overactivity. Here we review the intracellular signaling pathways involved in the generation of seizures in epileptogenic areas. Pathways activated by modulatory neurotransmitters (dopamine, norepinephrine, and serotonin), involving the activation of extracellular-regulated kinases and the induction of immediate early genes (IEGs) will be first discussed in relation to the occurrence of acute seizure events. Activation of IEGs has been proposed to lead to long-term molecular and behavioral responses induced by acute seizures. We also review deleterious consequences of seizure activity, focusing on the contribution of apoptosis-associated signaling pathways to the progression of the disease. A deep understanding of signaling pathways involved in both acute- and long-term responses to seizures continues to be crucial to unravel the origins of epileptic behaviors and ultimately identify novel therapeutic targets for the cure of epilepsy.

Keywords: Fos, ERK, activity-dependent transcription, seizure, apoptosis, hippocampus
BEHAVIORAL MANIFESTATIONS OF SEIZURES AND EPILEPSY Epilepsy is one of the most common neurological disorders, characterized by the repeated occurrence of sudden and transitory episodes of motor, sensory, autonomic, and psychic origin, known as seizures. Seizures typically arise in restricted regions of the brain and may remain confined to these areas ("focal" or "partial" seizures) or spread to the whole cerebral hemispheres ("generalized" seizures). The behavioral outcome of seizure events depends on the brain regions that are affected by overactivity. This is clearly exemplified by the behavioral manifestations of temporal lobe epilepsy (TLE), which represents one of the most common forms of human epilepsy. In TLE, focal seizures arise in a restricted part of the limbic system (temporal lobe: hippocampus, parahippocampal gyrus, and amygdala). If paroxysmal activity remains confined to the area of onset ("simple partial" seizure), the seizure may be characterized by auditory, gustatory, olfactory, visual, or somatosensory hallucinations (auras), accompanied by psychic sensations such as euphoria, fear, and anger. The seizure may also spread to a larger portion of the temporal lobe ("complex partial" seizure), resulting in impaired consciousness, motionless staring, motor automatisms of the hands or mouth, altered speech, and other unusual behaviors. Finally, partial seizures arising in the temporal lobe may subsequently spread to the whole brain ("secondarily generalized tonic-clonic" seizures or "grand mal" seizures). These seizures begin with symptoms of a partial seizure followed by whole-body convulsions (Berg et al., 2010).

Temporal lobe epilepsy can be reproduced in laboratory animals (typically rodents) by the systemic or intracerebral administration of powerful convulsant agents such as glutamatergic (kainic acid) or cholinergic (pilocarpine) agonists (Pitkänen et al., 2005). According to the classical scale originally proposed by Racine (1972), experimental seizures evoked in the temporal lobe in rodents can be scored on the basis of specific behaviors that correspond to different brain regions impacted by seizure activity. Stages from 1 to 3 are characterized by behavioral signs of focal seizure activity restricted to the temporal lobe (hippocampal formation, entorhinal cortex, and amygdala): immobility, rigid posture, forelimb and/or tail extension, repetitive movements, and head bobbing. When activity generalizes and spreads to cerebral hemispheres, isolated limbic motor seizures (forelimb clonus with rearing and falling; stage 4) or continuous convulsive activity (status epilepticus, stages 5-6: continuous rearing and falling, whole-body tonic-clonic convulsions) occur. Electroencephalographic (EEG) and metabolic mapping studies confirmed these behavioral observations. EEG analysis of experimentally induced limbic seizures showed that epileptic activity sequentially appears in forebrain areas, starting from the hippocampus and then spreading to the amygdala, and cerebral cortex (Lothman et al., 1981; Turski et al., 1989). Consistent with these results, glucose utilization studies in rodents at different times after limbic seizure induction revealed a progressive increase in several forebrain areas, starting in the hippocampus, amygdala, and other limbic areas and then diffusing to cerebral cortical areas (Lothman and Collins, 1981; Clifford et al., 1987).

In the past 25 years, a large series of studies addressed the crucial issue of how neurons transduce pathological electrical activity from their membrane to the nucleus, resulting in both short- and long-term rearrangements that modify neuronal connectivity in the epileptic brain and, ultimately, brain function, and behavior. Many of these mechanisms are now well characterized, whereas others still remain to be clearly understood. In the following sections, we will describe some of the major signaling pathways involved in shortand long-term cellular responses to seizure activity that are thought to underlie acute and chronic behaviors in the epileptic brain. 


\section{THE ACUTE CELLULAR RESPONSE TO SEIZURES: ACTIVATION OF IMMEDIATE EARLY GENES}

The first demonstration that pathological overactivity can modify gene expression in the brain came from the pioneering studies by J. I. Morgan and T. Curran, who showed that metrazole-induced seizures markedly induce c-fos mRNA expression in several areas of the rodent brain (Morgan et al., 1987). These authors first introduced the concept that neurons largely use the rapid activation of "immediate early genes" (IEGs; usually transcription factors, such as Fos and Jun) to couple acute and long-term responses to physiological as well as pathological stimuli (Morgan and Curran, 1989, 1991a). Induction of activity-regulated transcription factors is a general phenomenon occurring in neurons after acute seizures (Morgan and Curran, 1991b; Herrera and Robertson, 1996; Hughes et al., 1999). However, c-fos certainly remains the prototypical and well characterized activity-dependent transcription factor, and its induction is widely considered a suitable marker of neuronal activity. As originally demonstrated using fos-lacZ transgenic mice, seizures induce c-fos mRNA transcription in defined neuronal populations at different times (Smeyne et al., 1992). These observations have been confirmed by several studies using c-fos mRNA in situ hybridization or c-Fos immunostaining on rodent brain sections as a way to perform activity mapping studies after seizures. A precise correlation exists between the pattern of $\mathrm{c}$-fos induction and the progression of seizures from focal to generalized. Focal epileptic activity stimulates c-fos mRNA and c-Fos protein induction only in a few limbic areas, typically initiating in granule cell layer of the dentate gyrus and then spreading to CA3 and CA1 pyramidal layers. Then, when activity generalizes and limbic motor seizures and status epilepticus occur, a widespread c-fos mRNA and c-Fos protein expression is detected throughout the whole cerebral cortex and several other brain areas (Barone et al., 1993; Willoughby et al., 1997; Bozzi et al., 2000; Tripathi et al., 2008). More recent findings suggest that the increased level of phosphorylated ERK (pERK) could be one of the earliest immunohistochemical indicators of neurons that are activated at the time of a spontaneous seizure (Houser et al., 2008). In spontaneously epileptic animals, a marked increase in pERK labeling occurred at the time of spontaneous seizures and was evident in large populations of neurons at very short intervals (as early as $2 \mathrm{~min}$ ) after detection of a behavioral seizure.

The intracellular signaling cascades involved in IEGs activation in both physiological and pathological conditions have been extensively investigated in neurons. So far, the pathways involved in c-fos induction remain the best characterized and can be briefly summarized as a prototypical example of activity-dependent neuronal gene transcription. Neuronal depolarization leads to increased intracellular levels of the second messengers cAMP (typically, following neurotransmitter/neuromodulator binding to G-protein coupled receptors) and $\mathrm{Ca}^{2+}$ (e.g., due to ion channel opening following glutamate binding to glutamate receptors). Both these two second messengers activate intracellular kinases [protein kinase A and extracellular-regulated kinases (ERK)] whose activity converges on the phosphorylation of the transcription factor CREB (cAMP response element binding protein, constitutively present in the nucleus). In turn, CREB phosphorylation activates c-fos mRNA transcription. c-fos mRNA is then translated into the c-Fos protein, that acts as a transcription factor for a wide variety of neuron-specific genes (reviewed in West et al., 2002; Flavell and Greenberg, 2008). This mechanism is rapid, and allows neurons to fast couple depolarizing stimuli to a wide variety of intracellular long-lasting responses, including the induction of genes involved in synaptic plasticity and cell death (see below).

Intracellular cascades activated by seizures are largely overlapping those involved in synaptic plasticity, and more specifically in long-term memory (that requires IEGs induction and new protein synthesis). These cascades have been widely studied in the hippocampus, that is crucially involved in learning and memory, but is also one of the most epileptogenic brain areas. From these studies it emerges that hippocampal neurons use the same signaling pathways to respond to both physiological and pathological stimuli. However, these pathways are harmful only when activated by seizures and not physiological neuronal activity. Different types of activity pattern might elicit physiological or pathological responses of hippocampal neurons. For example, only epileptogenic stimuli (such as kainic acid and pilocarpine), but not other types of electrical stimulation, are able to rapidly $(3 \mathrm{~h})$ induce dendritic accumulation of BDNF mRNA and protein in hippocampal neurons (Tongiorgi et al., 2004), a change that is thought to contribute to the proepileptogenic action of BDNF (Simonato et al., 2006).

\section{SIGNALING PATHWAYS ACUTELY INDUCED BY SEIZURES: THE ROLE OF NEUROMODULATORS}

Seizures have been traditionally characterized as an imbalance between excitatory (glutamatergic) and inhibitory (GABAergic) transmission. The role of glutamate, GABA, and their respective signaling pathways in seizures and epilepsy has been extensively addressed in the literature (see for example McNamara et al., 2006; Ben-Ari et al., 2007) and will not be further reviewed here. Instead, we focus on the role that neuromodulatory systems have been shown to regulate seizure activity. The activities of dopamine, noradrenaline, and serotonin systems in modulating seizure threshold have been widely investigated, and all these neuromodulators have been shown to positively or negatively regulate the generation of seizures, depending on the receptors involved. However, the nature of the coupling of their receptors to intracellular signal transduction and, in particular, the induction of IEGs is still being investigated. Here, we describe the current state of knowledge of cell signaling pathways activated by neuromodulators and involved in seizure onset and propagation.

\section{CATECHOLAMINES: DOPAMINE AND NORADRENALINE}

The role of catecholamines (dopamine and noradrenaline) in the control of seizure onset and propagation has been widely addressed in experimental, clinical, and therapeutic studies (Starr, 1993, 1996; Weinshenker and Szot, 2002; Giorgi et al., 2004). However, the topic has received very little attention regarding the underlying signaling pathways activated by seizures. No data are available on the signaling cascades downstream of noradrenaline receptors during seizures, with the exception of a recent study addressing the role of noradrenergic neurons of the locus coeruleus (LC) in limbic seizure activity. LC neurons densely innervate limbic areas of the brain, greatly contributing to control seizure activity. LC neurons play an important role in determining IEG expression following seizures. Indeed, LC lesion markedly reduces seizure-induced Fos expression 
in the hippocampus, indicating that noradrenergic inputs to the limbic system positively control IEG transcription during seizures (Giorgi et al., 2008).

More studies instead investigated the signaling pathways downstream of dopamine receptors that might contribute to limbic seizure onset and spread. Dopamine acts through two different types of G-protein coupled receptors, named D1-like and D2-like receptors. Activation of D1-like (D1 and D5) receptors results in reduction of seizure threshold and increased seizure severity (DeNinno et al., 1991). Administration of a sub-threshold dose of pilocarpine in the presence of D1 receptor agonists has been shown to induce seizures (Starr and Starr, 1993). Conversely, the effect of D2-like (including D2, D3, and D4) receptors on seizure modulation is predominantly inhibitory. Administration of D2-like receptor agonists results in lower seizure activity, whereas blockade or genetic inactivation of these receptors has pro-convulsant effects (Starr, 1993, 1996; Bozzi et al., 2000; An et al., 2004; Bozzi and Borrelli, 2002, 2006).

The canonical pathway of dopamine receptor activity in neurons involves modulation of adenylate cyclase (AC) to regulate cAMP production and subsequent activation of protein kinase A (PKA). D1-like receptors are coupled to Gs/olf proteins and stimulate AC, leading to increased levels of the second messenger cAMP. Conversely, D2-like receptors are coupled to $\mathrm{Gi} / \mathrm{o}$ proteins and inhibit $\mathrm{AC}$, decreasing cAMP production (Callier et al., 2003). Pharmacological and targeted gene knockout studies provided some insight into the profile of these pathways explicitly in seizures. It appears that specific receptor coupling to AC may be critical in seizure induction by D1-like receptors (O'Sullivan et al., 2005). Stimulation of phospholipase C (PLC) signaling, however, does not appear to have any effect on seizure threshold (Clifford et al., 1999) and is associated with more subtle behaviors. Dopamine and cAMP-regulated phosphoprotein of $32 \mathrm{kDa}$ (DARPP32) has been identified as one of the critical downstream targets of dopamine and PKA. PKA-catalyzed phosphorylation activates DARPP-32, converting it into an inhibitor of protein phosphatase-1 (PP-1). Specifically, casein kinase 1 (CK1) promotes the activation of DARPP-32 by reducing calcineurin-dependent dephosphorylation at the PKA site. Phosphorylated DARPP-32, by inhibiting PP-1, acts together with other protein kinases (mainly PKA and PKC) to increase the level of phosphorylation of a number of downstream effector proteins, including GABA and glutamate receptors, $\mathrm{Ca}^{2+}$ and $\mathrm{Na}^{+}$channels, and the transcription factor CREB (Greengard et al., 1999; Greengard, 2001). DARPP-32 phosphorylation was observed in mice treated with D1-like receptor agonists and this elevation correlated with seizure behavior (O'Sullivan et al., 2008). The crucial role of DARPP-32 in mediating dopaminergic control of seizures was highlighted by the observation that seizure behaviors were absent or greatly reduced in DARPP-32 knockout mice (O'Sullivan et al., 2008).

As outlined previously, D2-like receptor stimulation appears to have an antagonistic effect to D1-like stimulation. Also acting on $\mathrm{AC}$, it can inhibit the activity of CAMP and reduce PKA activation (Missale et al., 1998). Moreover, D2 receptor (D2R) activation has been shown to downregulate DARPP-32 activity (Nishi et al., 1997). Recent evidence, however, suggests a role of an alternative pathway in D2R-modulated seizure behavior. Studies in the striatum suggested that a cAMP-independent pathway involves the formation of a signaling complex composed of D2R, Akt, protein phosphatase-2A
(PP2A), and $\beta$-arrestin 2. Activation of this pathway following binding of dopamine to D2R results in dephosphorylation of Akt (inactivation), followed by dephosphorylation (activation) of glycogen synthase kinase $3 \beta$ (GSK-3 $\beta$; Beaulieu et al., 2005, 2007). Similar activation of GSK-3 $\beta$ was observed in the hippocampus following KA administration in D2R knockout (D2 $\mathrm{R}^{-/}$) mice (Tripathi et al., 2010), suggesting that upregulation of GSK-3 $\beta$ activity might contribute to increased susceptibility to seizure-induced cell death observed in these mice. Indeed, activation of GSK-3 $\beta$ has been implicated in neuronal cell death (Kaytor and Orr, 2002). Importantly, GSK-3 $\beta$ upregulation was independent of any change in Akt in $\mathrm{D} 2 \mathrm{R}^{-/-}$mice following seizures (Tripathi et al., 2010), implicating that alternative pathways might contribute to modulate GSK-3 $\beta$ in the hippocampus during epileptic activity. p38MAPK and Wnt pathways have both been implicated as potential alternative pathways in regulating GSK-3 $\beta$ activity (Thornton et al., 2008; Inestrosa and Arenas, 2010), but require further investigation in the context of seizures.

In addition to its direct role on glutamatergic excitation (see above), ERK signaling is also believed to play an integral role in D1- and D2-type receptor signaling. Upregulation of ERK and increased phosphorylation of the ribosomal protein S6 and histone H3 (two downstream targets of ERK) were detected in the granule cell layer of the dentate gyrus, in response to brief seizures evoked by D1 specific agonists; these effects were prevented by genetic inactivation of D1 receptor, or by pharmacological inhibition of ERK (Gangarossa et al., 2011). Importantly, D1 receptor-mediated ERK upregulation disappeared within 60 min and correlated with seizure activity (Gangarossa et al., 2011). This is in contrast to kainic acid or pilocarpine-induced ERK upregulation, which can persist for hours (Kim et al., 1994; Berkeley et al., 2002). Thus, brief or long-lasting ERK activation in selective epileptogenic areas of the brain might contribute to activate signaling pathways in response to different seizure-promoting stimuli, as well as different types of seizure behaviors. Spontaneous chronic seizures following pilocarpine treatment rapidly induce ERK phosphorylation in the dentate gyrus specifically in a subpopulation of cells in the subgranular zone, that were identified as proliferating radial glia-like neural precursors ( $\mathrm{Li}$ et al., 2010b). The functional significance of ERK activation, and its link with the detrimental or beneficial effects of seizure-induced neurogenesis (Kokaia, 2011), remain to be clarified.

Seizure-induced ERK activation seems to be controlled also by D2R-dependent pathways. Following kainic acid treatment, more rapid and longer-lasting ERK phosphorylation is detected in the hippocampus of D2R $\mathrm{R}^{-/-}$mice, as compared to wild-type controls (Yuri Bozzi, unpublished observations). Downstream of ERK, the induction of IEGs is a critical effector step and has been extensively studied in seizure models (see above). D1-type receptor agonists increase the levels of Zif268 and Arc/Arg3.1 (two IEGs involved in transcriptional regulation and synaptic plasticity) in the dentate gyrus, with a time course that parallels that of ERK phosphorylation (Gangarossa et al., 2011).

Studies performed in $\mathrm{D} 2 \mathrm{R}^{-1-}$ mice confirm that dopaminergic innervation to the hippocampus plays a crucial role in seizureinduced IEGs induction. Experimentally induced seizures in these mice result in a more prominent upregulation of c-fos and c-jun mRNAs in the hippocampus, as compared to wild-type controls (Bozzi et al., 2000). As observed following administration of D1 
agonists in wild-type mice (Gangarossa et al., 2011), seizure-induced IEGs upregulation in $\mathrm{D} 2 \mathrm{R}^{-/}$mice was transient in the dentate gyrus (Bozzi et al., 2000), confirming the critical role of this structure in mediating the first steps of dopamine-dependent control of hippocampal activity during seizures.

\section{SEROTONIN}

Serotonin (5-hydroxytryptamine, 5-HT) acts through a family of predominantly G-protein coupled receptors to modulate neuronal excitability (Barnes and Sharp, 1999; Hannon and Hoyer, 2008). Activation of 5-HT receptors by administration of 5-HT agonists or reuptake inhibitors can inhibit focal and generalized seizures, while destruction of serotonergic terminals and depletion of brain 5 -HT results in reduction of seizure threshold and increased neuronal excitability in experimental models (Bagdy et al., 2007). More recently, increased threshold to kainic acid-induced seizures was observed in mice with genetically increased 5-HT levels (Tripathi et al., 2008).

Despite the well established role of 5-HT in seizure modulation, the receptor subtypes and signaling pathways through which 5-HT exerts its effect are not well characterized. Fourteen mammalian 5-HT receptor subtypes are currently recognized, and these have been classified into seven receptor families on the basis of their structural, functional and, to some extent, pharmacological characteristics (Barnes and Sharp, 1999; Hannon and Hoyer, 2008). Among these receptors, the $5-\mathrm{HT}_{1 \mathrm{~A}}$ and $5-\mathrm{HT}_{2 \mathrm{C}}$ subtypes, which are expressed in epileptogenic brain areas (mainly, cerebral cortex and/or hippocampus), appear to be the most relevant in epilepsy (Bagdy et al., 2007). For example, increased seizure severity is observed in mice with targeted inactivation of the $5-\mathrm{HT}_{1 \mathrm{~A}}$ or $5-\mathrm{HT}_{2 \mathrm{C}}$ genes (Tecott et al., 1995; Brennan et al., 1997; Sarnyai et al., 2000). However, it must be noted that pharmacological studies using the $5-\mathrm{HT}_{1}$ or $5-\mathrm{HT}_{2}$ specific agonist/antagonists failed to give a clear evidence of the general role played by these receptors in seizure modulation: contrasting results were obtained depending on the experimental seizure models used to test the anti- or pro-convulsant effect of different ligands. A detailed description of these findings is beyond the scope of this review and the reader is referred to more comprehensive previous studies (Bagdy et al., 2007).

Similar to dopamine, most of 5-HT receptors act on the AC/ cAMP/PKA pathway. The only exceptions are 5- $\mathrm{HT}_{2}$ receptors (that modulate $\mathrm{PLC}$ ) and the $5-\mathrm{HT}_{3 \mathrm{~A}}$ receptor (a ligand-gated ion channel; Bockaert et al., 2006; Hannon and Hoyer, 2008). 5-HT receptor signaling modulates IEGs induction in response to excitatory glutamatergic stimuli, such as those resulting from seizure activity. For example, the induction of Arc/Arg3.1 and c-fos in cortical neuronal populations following treatment with DOI (a 5- $\mathrm{HT}_{2}$ receptor agonist) is critically dependent on glutamate receptor activation (Pei et al., 2004). As regarding the neuromodulatory role of 5-HT on intracellular signaling pathways acutely induced by seizures, it is interesting to note that activation of the $5-\mathrm{HT}_{2} / \mathrm{PLC}$ pathway leads to phosphorylation of DARPP-32 (Svenningsson et al., 2002). The observation that pharmacological and genetic manipulations of $5-\mathrm{HT}_{2}$ receptors modulate seizure activity (see above; Bagdy et al., 2007) suggests that DARPP-32 may act as a converging point of the neuromodulatory action of both dopamine and 5-HT in seizure-induced signaling cascades.
Figure 1 summarizes the major signaling pathways downstream of dopamine and 5-HT receptors in the early response to seizures.

\section{SEIZURE-INDUCED CELL DEATH: INTRINSIC AND EXTRINSIC PATHWAYS}

Studies performed in both experimental models and findings in humans support the notion that seizures can be damaging to the brain. In particular, if seizures are prolonged (status epilepticus) or repeatedly evoked they can cause neuronal death, particularly within vulnerable brain

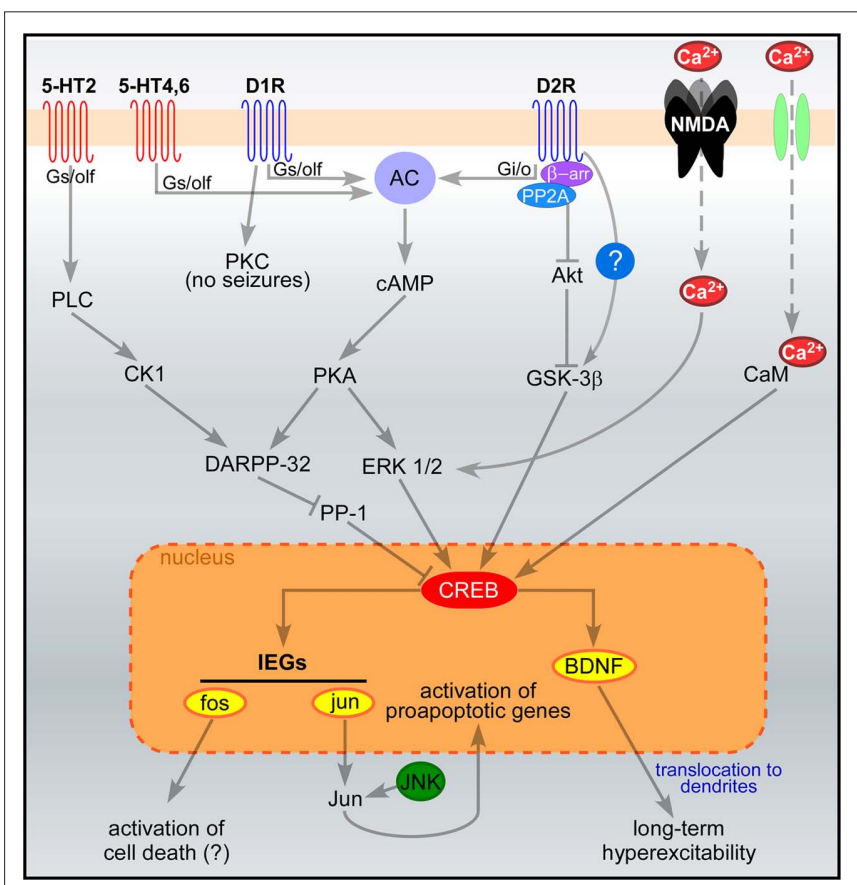

FIGURE 1 | Signaling pathways acutely activated in hippocampal neurons following seizures. Pathways downstream of glutamate, serotonin and dopamine receptors are illustrated. Seizures induce massive influx of $\mathrm{Ca}^{2+}$ through NMDA receptors and voltage-gated $\mathrm{Ca}^{2+}$ channels (in green), leading to CREB phosphorylation via ERK and calmodulin-dependent signaling, respectively (West et al., 2002). Serotonin and dopamine signaling modulate seizure-induced CREB phosphorylation via the activation of DARPP-32 and ERK1/2. Once phosphorylated, CREB promotes the transcription of activity-dependent genes such as BDNF and the IEGs fos and jun. The sustained induction of jun has been shown to switch on apoptotic cascades, whereas the pro-apoptotic role of fos induction has been questioned. Dendritic localization of BDNF mRNA and protein may also contribute to long-term excitability. The proposed scheme is a general (though not complete) summary of the intracellular pathways induced by seizures in the hippocampus. All the reported serotonin and dopamine receptor subtypes are expressed in the hippocampus, together with their signaling proteins (Meador-Woodruff et al., 1991; Perez and Lewis, 1992; Hannon and Hoyer, 2008). However, important differences may occur in different types of hippocampal neurons (e.g., dentate granule cells, pyramidal neurons), due to the different expression levels of these proteins. Abbreviations: $A C$, adenylate cyclase; CaM, calmodulin; CK1, casein kinase 1; DARPP-32, dopamine and cAMP-regulated phosphoprotein of $32 \mathrm{kDa}$; D1R and D2R, dopamine receptors (D1 and D2 subtypes); ERK, extracellular-regulated kinase; GSK-3 $\beta$, glycogen synthase kinase $3 \beta$; IEGs, immediate early genes; JNK, Jun-terminal kinase; NMDA, NMDA glutamate receptors; PKA, protein kinase $A$; PKC, protein kinase C; PLC, phospholipase C; PP-1, protein phosphatase 1; 5-HT, serotonin receptors. Question marks indicate that some pathways have been proposed but not clearly demonstrated. 
regions such as the hippocampus. Cell death is a common pathologic feature of insults to the brain which trigger a chronic epileptic condition (Pitkanen and Sutula, 2002). The main mechanism by which neurons die after seizures is excitotoxicity due to prolonged over-activation of ionotropic glutamate receptors (Choi, 1988; Meldrum, 1991; Fujikawa, 2005). An appreciation of the complex molecular pathways lying downstream of glutamate receptor over-activation has emerged, alongside evidence that glutamate receptor antagonists do not block all cell death after seizures (Bengzon et al., 1997).

Several studies have addressed the role of IEGs in seizure-induced cell death (Herdegen and Leah, 1998). The prolonged activation of the IEGs c-fos and c-jun after acute seizures was originally proposed as one of the crucial steps that trigger long-term neuronal death (Smeyne et al., 1993; Kasof et al., 1995; Kondo et al., 1997). In physiological conditions, IEGs are essential for normal neuronal responses to excitation in the brain. The protein products of fos/jun contribute to assembly of the AP-1 transcription factor, whose activation regulates the expression of a wide number of "synaptic" genes, including neurotrophic factors (Sheng and Greenberg, 1990). Indeed, loss of c-fos in mice markedly reduces activity-dependent structural plasticity (mossy fiber sprouting; Watanabe et al., 1996). This suggests that such a "fos-less phenotype" might be due to altered seizure-induced transcriptional activation of genes involved in synaptic plasticity (Watanabe et al., 1996). However, the role of c-fos as a promoting agent of seizureinduced neuronal cell death has been questioned by the observation that conditional mutant mice lacking c-fos in the hippocampus display increased susceptibility to seizure-dependent neuronal loss (Zhang et al., 2002). Conversely, the pro-apoptotic activity of c-jun activation has been confirmed in several experimental models. Increased levels of both c-jun mRNA and Jun phosphorylation are observed in epileptogenic areas after seizures (Huges et al., 1999; Raivich and Behrens, 2006). Phosphorylation of Jun is mediated by the c-Jun $\mathrm{N}$-terminal kinase (JNK) and results in the subsequent activation of Jun transcriptional activity, that triggers apoptotic neuronal cell death after seizures (Herdegen et al., 1998; Behrens et al., 1999; Mielke et al., 1999; Schauwecker, 2000; Spigolon et al., 2010) and other traumatic insults (Yuan and Yankner, 2000). Accordingly, mice lacking the Junterminal kinase Jnk3 are protected against seizure-induced apoptosis in the hippocampus (Yang et al., 1997).

Apoptosis-associated signaling pathways are important components of the molecular response to seizures (Engel and Henshall, 2009). Complex intracellular and intercellular cell death-regulatory pathways are increasingly recognized as important contributors to seizure-induced neuronal death. Here, we review the latest findings on apoptosis-associated signaling pathways, in particular the role of Bcl-2 family proteins, as critical components of the molecular response to seizures.

Apoptosis is a form of programmed cell death that is orchestrated by evolutionarily-conserved signaling pathways. Two main pathways have been identified. The intrinsic pathway is activated by various intracellular stressors such as DNA damage, perturbed intracellular organelle function (for example, prolonged endoplasmic reticulum stress), and loss of calcium homeostasis (Orrenius et al., 2003; Xu et al., 2005). Ultimately, this results in mitochondrial outer membrane permeabilization (MOMP) and release of apoptogenic molecules from mitochondria, in particular cytochrome c. Having transited from the inter-membrane space to the cytoplasm, cytochrome $\mathrm{c}$ binds the apoptotic protease activating factor 1 (Apaf-1) which recruits caspase-9, a long pro-domain-containing member of the caspase family of cysteinyl aspartate-specific proteases. This forms the so-called apoptosome which processes downstream effector caspases such as caspase-3, culminating in cleavage of various structural and other proteins and, finally, cell death. The extrinsic pathway is activated when cytokines such as Fas ligand bind surface-expressed death receptors of the tumor necrosis factor (TNF) superfamily (Ashkenazi and Dixit, 1998). Upon binding, receptors recruit intracellular adaptor proteins such as Fas-associated death domain protein (Fadd) which can activate caspase-8, followed by effector caspases (Wilson et al., 2009).

Apoptosis-inducing factor (AIF) is a critical mediator of caspaseindependent apoptosis. AIF is released from mitochondria whereupon it translocates to the nucleus and mediates large scale DNA fragmentation and nuclear condensation (Hangen et al., 2010). AIF release is triggered by various insults including excitotoxicity and AIF can be blocked in some models by Bcl-2 (Susin et al., 1999).

\section{BcI-2 FAMILY}

Control over MOMP and the downstream caspase-dependent and, possibly, AIF/caspase-independent cell death process, rests with the $\mathrm{Bcl}-2$ family proteins. The family is characterized by the presence of one or more $\mathrm{Bcl}-2$ homology $(\mathrm{BH})$ domains and is divided into antiapoptotic members, including Bcl-2 and Bcl-XL, and pro-apoptotic members. Within the pro-apoptotic family there are the multi-BH domain proteins, Bax and Bak, and the BH3-only subgroup. BH3only proteins are the sentinels of cell stress. At least 10 members have been identified which share homology within the short $\mathrm{BH} 3$ domain but are otherwise structurally unrelated (Youle and Strasser, 2008). Some members are constitutively expressed in cells, requiring release from chaperones or post-translational modification to become active. Others are not normally present and require transcriptional upregulation. Two non-mutually exclusive mechanisms have been proposed for how $\mathrm{BH} 3$-only proteins promote MOMP. First, BH3only proteins bind to anti-apoptotic members thereby neutralizing them. This displaces and allows activation of the multi-BH domain proteins Bax/Bak to trigger MOMP. A second mechanism is the direct activator model whereby $\mathrm{BH} 3$-only proteins directly activate Bax/ Bak by binding and promoting their integration into mitochondria (Youle and Strasser, 2008; Chipuk et al., 2010). There is a hierarchy among BH3-only proteins with so-called "weak" members such as Bad having restricted affinity for only few anti-apoptotic Bcl-2 family proteins and unable to directly activate $\mathrm{Bax} / \mathrm{Bak}$, whereas potent members of the BH3-only family including Bim, Bid, and probably Puma can avidly bind all anti-apoptotic Bcl-2 family proteins and directly activate Bax/Bak (Youle and Strasser, 2008; Chipuk et al., 2010). Activation of pro-apoptotic Bcl-2 family proteins, in particular Bax and Bid, may also directly cause mitochondrial fragmentation that contributes to cell death (Youle and Karbowski, 2005).

\section{INDUCTION OF APOPTOSIS-ASSOCIATED SIGNALING PATHWAYS AFTER ACUTE SEIZURES}

There is substantial evidence that prolonged or repeated seizures activate apoptosis-associated signaling in vivo (Engel and Henshall, 2009). Within a few hours of status epilepticus there is release of cytochrome $c$ and other pro-apoptogenic molecules from 
mitochondria and an ensuing caspase cascade, and neuronal death can be interrupted using caspase inhibitors (Henshall et al., 2000a, 2001a,b; Viswanath et al., 2000; Narkilahti et al., 2003a; Li et al., 2006; Manno et al., 2007; Murphy et al., 2007).

Seizures also activate caspase-independent apoptosis pathways in the brain (Cheung et al., 2005; Takano et al., 2005; Engel et al., 2010a; Zhao et al., 2010). Here, calpains are thought to be critical. There are over 60 known calpain substrates and calpain is viewed as a critical coordinator of calcium-dependent signaling pathways underlying neuronal death (Vosler et al., 2008). Calpain inhibitors have proven to be effective neuroprotectants in models of status epilepticus (Araujo et al., 2008; Wang et al., 2008). Recently, calpain I ( $\mu$-calpain) was shown to be responsible for triggering AIF release during excitotoxicity (Cao et al., 2007). Thus, calpain and AIF may be particularly important for neuronal death in seizure models in which caspases are not activated (Fujikawa et al., 2007; Wang et al., 2008; Zhao et al., 2010).

\section{BCI-2 FAMILY PROTEINS IN SEIZURE-INDUCED NEURONAL DEATH}

In vivo delivery of $\mathrm{Bcl}-\mathrm{XL}$ or $\mathrm{Bcl}-2$ in rodents can prevent neuronal death following excitotoxin administration in vivo (Lawrence et al., 1996; Ju et al., 2008). Also, mice lacking another anti-apoptotic member Bcl-w were found to be more vulnerable to seizures and to develop significantly more hippocampal damage after status epilepticus (Murphy et al., 2007). Thus, anti-apoptotic Bcl-2 family members protect against seizure-induced neuronal death in animal models.

Among the multi-BH domain proteins, Bax has been shown to accumulate at mitochondria after seizures (Henshall et al., 2002) but we await in vivo functional studies. Some in vitro data support a role for Bax in glutamate-induced neuronal death (Xiang et al., 1998), but other studies have reported bax-deficient neurons are equally vulnerable to excitotoxicity (Dargusch et al., 2001; Cheung et al., 2005). Bak does not appear to promote neuronal death in adult brain (Fannjiang et al., 2003) and there are no in vivo data on the third multi-BH domain member, Bok.

At least six members of the BH3-only subfamily have been studied in seizure models, including each of the potently pro-apoptotic BH3-only subgroup (Engel et al., 2011). Bid is rapidly cleaved to its more active form after seizures (Henshall et al., 2001b; Li et al., 2006; Engel et al., 2010a). Bim and Puma are both up-regulated after seizures, accumulate in the hippocampus and bind anti-apoptotic Bcl-2 family proteins (Shinoda et al., 2004; Engel et al., 2010c; Murphy et al., 2010). Among the less potent members, there is evidence for activation of Bad after seizures (Henshall et al., 2002; Noh et al., 2006) while two other BH3-only proteins examined, Noxa and Hrk, were not induced (Korhonen et al., 2003; Engel et al., 2010c).

\section{Signaling pathways linking seizures to activation of BH3-only proteins}

How are the various $\mathrm{BH} 3$-only proteins activated by seizures? For Bad, the trigger is thought to be dephosphorylation by the calcium-regulated phosphatase calcineurin (Henshall et al., 2002). Puma upregulation after seizures is largely p53-mediated. Indeed, pharmacologic inhibition of p53 prevents Puma induction after status epilepticus and Puma is not up-regulated after seizures in p53-deficient mice (Engel et al., 2010c). The trigger for p53 accumulation after seizures may be DNA damage, which is an early consequence of seizures in vivo (Henshall et al., 1999; Lan et al., 2000), but other stimuli including raised intracellular calcium could be responsible (Sedarous et al., 2003).

Bim has several transcriptional control mechanisms (Biswas et al., 2007; Puthalakath et al., 2007; Concannon et al., 2010). The FoxO1/3a transcription factors were the first to be linked to Bim regulation after status epilepticus (Shinoda et al., 2004), but more recent work has implicated c-Jun N-terminal kinase (JNK; Murphy et al., 2010). Indeed, in vivo injection of the JNK inhibitor SP600125 fully blocked Bim induction after status epilepticus in mice (Murphy et al., 2010). Activation of JNK itself may occur via stimulation of the KA receptor subunit GluR6 recruiting post-synaptic density protein 95 (PSD-95) and mixed lineage kinases, which activate JNK (Savinainen et al., 2001; Li et al., 2010a). This signaling scaffold also mediates the degradation of Bcl-2 after seizures (Zhang et al., 2011). JNK can also be activated downstream of TNF receptor 1 and endoplasmic reticulum stress (Yang et al., 2006), which are both early events following seizures (Shinoda et al., 2003; Murphy et al., 2010). Last, in vitro data show the adenosine monophosphate-activated protein kinase (AMPK) mediates Bim-induced neuronal death during excitotoxicity (Concannon et al., 2010), although this has not been explored in vivo.

Caspase- 8 has been implicated in the mechanism of Bid activation after seizures on the basis that caspase- 8 pseudosubstrate inhibitors reduced Bid cleavage (Henshall et al., 2001b; Li et al., 2006). Whether this is downstream of death receptors is unknown. Bid can also be activated by calpain (Mandic et al., 2002) and in some models cleavage of Bid may not be needed for mitochondrial translocation and neuronal apoptosis (Konig et al., 2007).

\section{In vivo evidence that BH3-only proteins regulate neuronal death after seizures}

Seizure-induced neuronal death has recently been studied in animals lacking each of the potently pro-apoptotic $\mathrm{BH} 3$-only proteins (Engel et al., 2011). Mice deficient in Puma are the most protected against seizure-induced neuronal death, with seizuredamage reduced by over 70\% (Engel et al., 2010c). Puma-deficient mice were also protected when the severity of status epilepticus was increased to produce a stronger necrotic component (Engel et al., 2010 b). Seizure-damage in the hippocampus of Bim-deficient mice was reduced by $\sim 45 \%$ in the same model (Murphy et al., 2010). In another study, however, bim-l- mice were not protected against intra-hippocampal KA-induced damage (Theofilas et al., 2009).

Seizure-induced hippocampal damage in Bid-deficient mice was not different to wild-type animals (Engel et al., 2010a). This was surprising because Bid-deficient mice were protected against stroke and traumatic brain injury, and bid-/-neurons are protected in vitro from glutamate excitotoxicity (Plesnila et al., 2001; Bermpohl et al., 2006). Of note, Puma-deficient mice are not protected against ischemic brain damage (Kuroki et al., 2009). This suggests there are differences in the contributions of $\mathrm{BH} 3$-only proteins to the patho-mechanisms of seizure versus ischemic damage as well as gaps between the relatedness of in vitro and in vivo models (Engel et al., 2011).

\section{Bcl-2 family proteins in experimental epilepsy}

Activation of apoptosis-associated signaling pathways also extends into the period of epileptogenesis and chronic recurrent seizures (i.e., epilepsy). Indeed, recent transcriptome profiling of rat brain 
found changes to apoptosis-associated genes were associated with all stages of epileptogenesis (Okamoto et al., 2010). We know little, however, about the role of Bcl-2 family proteins in epilepsy development. Puma-deficient mice were found to develop fewer epileptic seizures than wild-type animals after status epilepticus (Engel et al., 2010c), but there are no data on Puma levels in wild-type epileptic mice. Also, the influence of Puma deficiency on epileptogenesis is complicated by the neuroprotection afforded by its absence during the initial precipitating injury. Studies of brief evoked seizures, which model some aspects of epileptic seizures, show expression changes for a small number of $\mathrm{Bcl}-2$ family proteins but functional studies are needed to determine whether they are active during the process of epileptogenesis or after epileptic seizures (Engel and Henshall, 2009).

\section{Bcl-2 family proteins in human epilepsy}

The expression of several members of the Bcl-2 family has been examined in human hippocampus and neocortex samples resected from patients with TLE (Engel and Henshall, 2009). Overall, the patterns favor an adapted, anti-apoptotic state which may function to limit seizure-induced neuronal death; Bcl-2, Bcl-w, and Bcl-XL are all expressed at higher levels in TLE samples than controls and levels of Bim are lower (Henshall et al., 2000b; Shinoda et al., 2004; Murphy et al., 2007; Engel and Henshall, 2009). Modest upregulation of Bax has been reported in some TLE studies while no changes have been reported for Bad or Bid (Engel and Henshall, 2009). Bcl-2, Bcl-XL, and Bax may also be aberrantly expressed in focal cortical dysplasia, another common cause of pharmacoresistant epilepsy (Chamberlain and Prayson, 2008).

\section{OTHER APOPTOSIS-ASSOCIATED SIGNALING PATHWAYS DURING EPILEPTOGENESIS AND IN CHRONIC EPILEPSY}

Several other apoptosis-associated genes have been examined during epileptogenesis and in chronic epilepsy. Immunohistochemistry and enzyme assays show caspase- 3 is active several days and even a week after status epilepticus (Narkilahti et al., 2003b; Weise et al., 2005). Other caspases have similarly been found to be cleaved and/ or active during epileptogenesis and in epileptic brain in experimental models (Engel and Henshall, 2009). Over-expression and cleavage of caspases-1, 2, 3, 6, 7, and 9 have also been identified in resected human TLE tissue (Engel and Henshall, 2009).

\section{NON-CELL DEATH FUNCTIONS OF APOPTOSIS-ASSOCIATED SIGNALING MOLECULES}

It is recognized that several proteins involved in apoptosis have noncell death-related biological functions (Galluzzi et al., 2008; Lamb and Hardwick, 2010). Caspase-1, a member of the non-apoptotic subgroup, is the enzyme responsible for interleukin-1 $\beta$ (IL-1 $\beta$ ) production. An inflammatory cytokine, IL-1 $\beta$ is pro-convulsive, prolonging seizures, while inhibitors of IL- $1 \beta$ and caspase- 1 have potent anti-convulsive effects (Vezzani et al., 2010). A role for caspase activation has also been demonstrated in microglial activation (Burguillos et al., 2011). Apoptotic caspases, including caspases- 2 and 6 , have been found to localize to the dendritic fields of the hippocampus in the wake of experimental status epilepticus (Narkilahti and Pitkanen, 2005; Narkilahti et al., 2007). Similar patterns of staining for caspases-2, 3 , and 9 have been found in hippocampal tissue from TLE patients. This likely reflects roles for caspases in dendritic pruning and synaptic plasticity (D'amelio et al., 2010). Most recently, Bad, Bax, and caspase-3 have been proposed in long-term depression of synaptic transmission (Li et al., 2010c; Jiao and Li, 2011). These non-cell death functions are almost certainly of relevance to epilepsy. Only a single study has explored the effects of caspase inhibition on epilepsy, however, and results were negative (Narkilahti et al., 2003a). Nevertheless, if caspases and certain Bcl-2 family proteins influence the post-insult remodeling process and exert direct influences on excitability then they represent therapeutic targets of interest long-after the initial precipitating injury.

Other apoptosis-associated molecules have neuromodulatory effects. TNF $\alpha$ is known to promote AMPA receptor function (Stellwagen and Malenka, 2006) and Bcl-w has been associated with GABA receptor signaling (Murphy et al., 2007). It is likely further non-cell death functions will emerge for apoptosis-associated signaling molecules.

Taken together, studies on apoptosis-associated signaling in epilepsy have revealed a widespread role which spans contributions to early as well as late cell death and a variety of non-cell death-regulatory functions including seizure thresholds and processes which may impact on epileptogenesis and the chronic epileptic state.

The intracellular pathways involved in long-term neuronal cell death after seizures are illustrated in Figure 2.

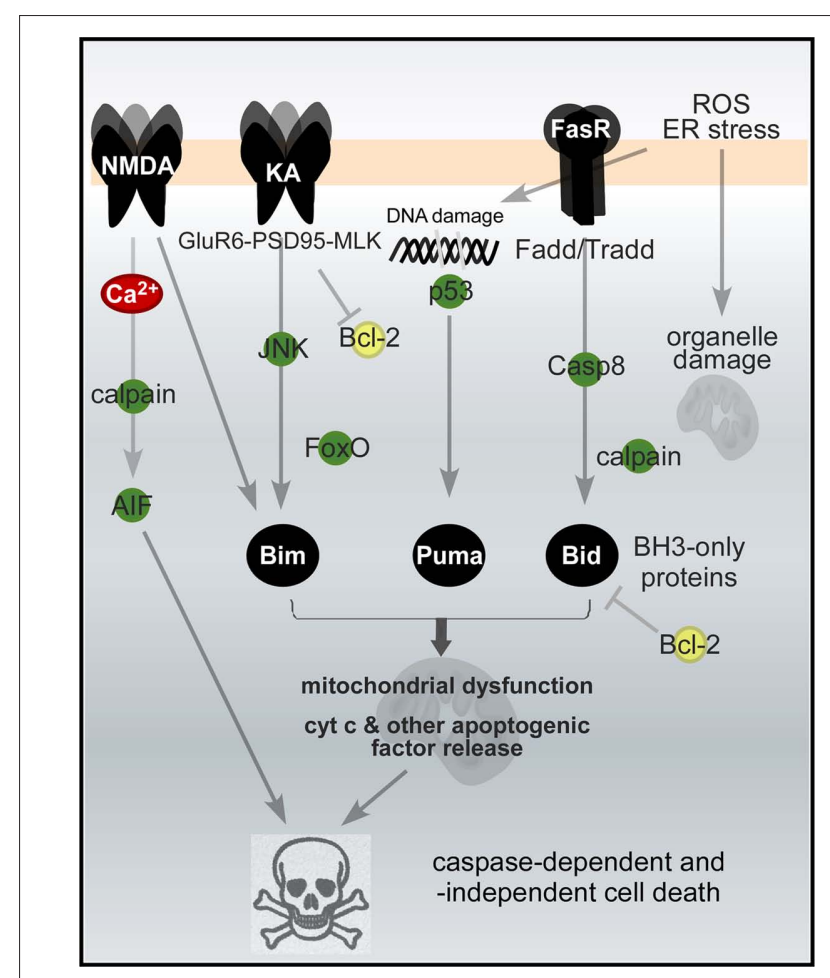

FIGURE 2 |Apoptosis-associated signaling pathways activated in neurons by seizures. Signaling pathways downstream of glutamate and Fas (death) receptors turn on $\mathrm{BH} 3-$ only proteins of the $\mathrm{Bcl}-2$ family, culminating in mitochondrial dysfunction and caspase-dependent and -independent cell death. The list is not complete and represents only some of the major pathways. Abbreviations: AIF, apoptosis-inducing factor; casp8, caspase-8; ER, endoplasmic reticulum; Fadd, Fas-associated death domain protein; FasR, Fas death receptor; JNK, Jun-terminal kinase; KA and NMDA, glutamate receptor subtypes; ROS, reactive oxygen species. 


\section{CONCLUSION}

The activation of cell signaling pathways in response to acute seizures has detrimental long-term effects. Upregulation of IEGs induced by pathological overactivity results in plastic changes that alter synaptic functions and neuronal connectivity in susceptible brain areas. IEGs induction after seizures has been described to lead to neuronal death in several regions of the brain, including the hippocampus and the limbic system. These structures are among the most epileptogenic areas of the brain, and are crucially involved in learning and memory processes. In addition, studies on apoptosis-associated signaling in epilepsy have revealed a widespread role which spans contributions to early as well as late cell death and a variety of non-cell death-regulatory functions including seizure thresholds and processes which may impact on epileptogenesis and the chronic epileptic state. Thus, the activation of cell signaling pathways after seizures (markedly depending

\section{REFERENCES}

An, J. J., Bae, M. H., Cho, S. R., Lee, S. H., Choi, S. H., Lee, B. H., Shin, H. S., Kim, Y.N., Park, K. W., Borrelli, E., and Baik, J. H. (2004). Altered GABAergic neurotransmission in mice lacking dopamine D2 receptors. Mol. Cell. Neurosci. 25, 732-741.

Araujo, I. M., Gil, J. M., Carreira, B. P., Mohapel, P., Petersen, A., Pinheiro, P. S., Soulet, D., Bahr, B. A., Brundin, P., and Carvalho, C. M. (2008). Calpain activation is involved in early caspase-independent neurodegeneration in the hippocampus following status epilepticus. J. Neurochem. 105, 666-676.

Ashkenazi, A., and Dixit, V. M. (1998). Death receptors: signaling and modulation. Science 281, 1305-1308.

Bagdy, G., Kecskemeti, V., Riba, P., and Jakus, R. (2007). Serotonin and epilepsy. J. Neurochem. 100, 857-873.

Barnes, N. M., and Sharp, T. (1999). A review of central 5-HT receptors and their function. Neuropharmacology 38 , 1083-1152.

Barone, P., Morelli, M., Cicarelli, G., Cozzolino, A., Dejoanna, G., Campanella, G., and Dichiara, G. (1993). Expression of c-fos protein in the experimental epilepsy induced by pilocarpine. Synapse 14, 1-9.

Beaulieu, J. M., Gainetdinov, R. R., and Caron, M. G. (2007). The Akt-GSK-3 signaling cascade in the actions of dopamine. Trends Pharmacol. Sci. 28, 166-172.

Beaulieu, J. M., Sotnikova, T. D., Marion, S., Lefkowitz, R. J., Gainetdinov, R. R., and Caron, M. G. (2005). An Akt/ beta-arrestin 2/PP2A signaling complex mediates dopaminergic neurotransmission and behavior. Cell 122, 261-273.

Behrens, A., Sibilia, M., and Wagner, E. F. (1999). Amino-terminal phosphorylation of c-Jun regulates stress-induced apoptosis and cellular proliferation. Nat. Genet. 21, 326-329.

Ben-Ari, Y., Gaiarsa, J. L., Tyzio, R., and Khazipov, R. (2007). GABA: a pioneer transmitter that excites immature neurons and generates primitive oscillations. Physiol. Rev. 87, 1215-1284.

Bengzon, J., Kokaia, Z., Elmer, E., Nanobashvili, A., Kokaia, M., and Lindvall, O. (1997). Apoptosis and proliferation of dentate gyrus neurons after single and intermittent limbic seizures. Proc. Natl. Acad. Sci. U.S.A. 94, 10432-10437.

Berg, A. T., Berkovic, S. F., Brodie, M. J., Buchhalter, J., Cross, J. H., Van Emde Boas, W., Engel, J., French, J., Glauser, T. A., Mathern, G. W., Moshe, S. L., Nordli, D., Plouin, P., and Scheffer, I. E. (2010). Revised terminology and concepts for organization of seizures and epilepsies: report of the ILAE Commission on Classification and Terminology, 2005-2009. Epilepsia 51, 676-685.

Berkeley, J.L., Decker, M. J., and Levey, A. I. (2002). The role of muscarinic acetylcholine receptor-mediated activation of extracellular signal-regulated kinase $1 / 2$ in pilocarpine-induced seizures. J. Neurochem. 82, 192-201.

Bermpohl, D., You, Z., Korsmeyer, S. J., Moskowitz, M. A., and Whalen, M. J. (2006). Traumatic brain injury in mice deficient in Bid: effects on histopathology and functional outcome. J. Cereb. Blood Flow Metab. 26, 625-633.

Biswas, S. C., Shi, Y., Sproul, A., and Greene, L. A. (2007). Pro-apoptotic Bim induction in response to nerve growth factor deprivation requires simultaneous activation of three different death signaling pathways. J. Biol. Chem. 282, 29368-29374.

Bockaert, J., Claeysen, S., Becamel, C., Dumuis, A., and Marin, P. (2006). Neuronal5-HT metabotropic receptors: fine-tuning of their structure, signaling,

on the neuromodulatory action of catecholaminergic and serotonergic systems) has dramatic long-term consequences such as neuronal loss, behavioral changes and irreversible loss of function. Understanding these mechanisms remains a crucial issue to unravel the origins of epileptic behaviors and ultimately identify a cure for chronic epileptic disorders.

\section{ACKNOWLEDGMENTS}

Mark Dunleavy is a postdoctoral fellow supported by IRCSET (Ireland) under the Marie Curie-People cofunding action of the European Community. This work was funded by the Italian Ministry of University and Research (PRIN 2008 grant \# 200894SYW2_002 to Yuri Bozzi), and the Italian Ministry of Health (grant RF-TAA-2008-1141282 to Yuri Bozzi) and Health Research Board (grant RP/2007/37 to David C. Henshall) and Science Foundation Ireland (grant 08/IN.1./B1875 to David C. Henshall).

and roles in synaptic modulation. Cell Tissue Res. 326, 553-572.

Bozzi, Y., and Borrelli, E. (2002). Dopamine D2 receptor signaling controls neuronal cell death induced by muscarinic and glutamatergic drugs. Mol. Cell. Neurosci. 19, 263-271.

Bozzi, Y., and Borrelli, E. (2006). Dopamine in neurotoxicity and neuroprotection: what do D2 receptors have to do with it? Trends Neurosci. 29, 167-174.

Bozzi, Y., Vallone, D., and Borrelli, E. (2000). Neuroprotective role of dopamine against hippocampal cell death. J. Neurosci. 20, 8643-8649.

Brennan, T. J., Seeley, W. W., Kilgard, M., Schreiner, C. E., and Tecott, L. H. (1997). Sound-induced seizures in serotonin 5 -HT2c receptor mutant mice. Nat. Genet. 16, 387-390.

Burguillos, M.A., Deierborg, T., Kavanagh, E., Persson, A., Hajji, N., GarciaQuintanilla, A., Cano, J., Brundin, P., Englund, E., Venero, J. L., and Joseph, B. (2011). Caspase signalling controls microglia activation and neurotoxicity. Nature 472, 319-324.

Callier, S., Snapyan, M., Le Crom, S., Prou, D., Vincent, J. D., and Vernier, P. (2003). Evolution and cell biology of dopamine receptors in vertebrates. Biol. Cell 95, 489-502.

Cao, G., Xing, J., Xiao, X., Liou, A. K., Gao, Y., Yin, X. M., Clark, R. S., Graham, S. H., and Chen, J. (2007). Critical role of calpain I in mitochondrial release of apoptosis-inducing factor in ischemic neuronal injury. J. Neurosci. 27, 9278-9293.

Chamberlain, W. A., and Prayson, R. A. (2008). Focal cortical dysplasia type II (malformations of cortical development) aberrantly expresses apoptotic proteins. Appl. Immunohistochem. Mol. Morphol. 16, 471-476.

Cheung, E. C., Melanson-Drapeau, L., Cregan, S. P., Vanderluit, J. L.,
Ferguson, K. L., Mcintosh, W. C., Park, D. S., Bennett, S. A., and Slack, R. S. (2005). Apoptosis-inducing factor is a key factor in neuronal cell death propagated by BAX-dependent and BAX-independent mechanisms. J. Neurosci. 25, 1324-1334.

Chipuk, J. E., Moldoveanu, T., Llambi, F., Parsons, M. J., and Green, D. R. (2010). The BCL-2 family reunion. Mol. Cell 37, 299-310.

Choi, D. W. (1988). Glutamate neurotoxicity and diseases of the nervous system. Neuron 1, 623-634.

Clifford, D. B., Olney, J. W., Maniotis, A., Collins, R. C., and Zorumski, C. F. (1987). The functional anatomy and pathology of lithium-pilocarpine and high-dose pilocarpine seizures. Neuroscience 23, 953-968.

Clifford, J. J., Tighe, O., Croke, D. T., Kinsella, A., Sibley, D. R., Drago, J., and Waddington, J. L. (1999). Conservation of behavioural topography to dopamine D1-like receptor agonists in mutant mice lacking the D1A receptor implicates a D1-like receptor not coupled to adenylyl cyclase. Neuroscience 93, 1483-1489.

Concannon, C. G., Tuffy, L. P., Weisova, P., Bonner, H. P., Davila, D., Bonner, C., Devocelle, M. C., Strasser, A., Ward, M. W., and Prehn, J. H. (2010). AMP kinase-mediated activation of the $\mathrm{BH} 3$-only protein Bim couples energy depletion to stress-induced apoptosis. J. Cell Biol. 189, 83-94.

D'amelio, M., Cavallucci, V., and Cecconi, F. (2010). Neuronal caspase-3 signaling: not only cell death. Cell Death Differ. 17, 1104-1114.

Dargusch, R., Piasecki, D., Tan, S., Liu, Y., and Schubert, D. (2001). The role of Bax in glutamate-induced nerve cell death. J. Neurochem. 76, 295-301.

DeNinno, M. P., Schoenleber, R., Perner, R. J., Lijewski, L., Asin, K. E., Britton, D. R., Mackenzie, R., and Kebabian, 
J. W. (1991). Synthesis and dopaminergic activity of 3-substituted 1-(aminomethyl)-3,4-dihydro5,6-dihydroxy-1H-2-benzopyrans: characterization of an auxiliary binding region in the D1 receptor. J. Med. Chem. 34, 2561-2569.

Engel, T., Caballero-Caballero, A., Schindler, C. K., Plesnila, N., Strasser, A., Prehn, J. H., and Henshall, D. C. (2010a). BH3-only protein Bid is dispensable for seizure-induced neuronal death and the associated nuclear accumulation of apoptosis-inducing factor. J. Neurochem. 115, 92-101.

Engel, T., Hatazaki, S., Tanaka, K., Prehn, J. H., and Henshall, D. C. (2010b). Deletion of puma protects hippocampal neurons in a model of severe status epilepticus. Neuroscience 168, 443-450.

Engel, T., Murphy, B. M., Hatazaki, S., Jimenez-Mateos, E. M., Concannon, C. G., Woods, I., Prehn, J. H., and Henshall, D. C. (2010c). Reduced hippocampal damage and epileptic seizures after status epilepticus in mice lacking proapoptotic Puma. FASEB J. 24, 853-861.

Engel, T., and Henshall, D. C. (2009). Apoptosis, Bcl-2 family proteins and caspases: the ABCs of seizure-damage and epileptogenesis? Int. J. Physiol. Pathophysiol. Pharmacol. 1, 97-115.

Engel, T., Plesnila, N., Prehn, J. H., and Henshall, D. C. (2011). In vivo contributions of $\mathrm{BH} 3$-only proteins to neuronal death following seizures, ischemia, and traumatic brain injury. J. Cereb. Blood Flow Metab. 31, 1196-1210.

Fannjiang, Y., Kim, C. H., Huganir, R. L., Zou, S., Lindsten, T., Thompson, C. B., Mito, T., Traystman, R. J., Larsen, T., Griffin, D. E., Mandir, A. S., Dawson, T. M., Dike, S., Sappington, A. L., Kerr, D. A., Jonas, E. A., Kaczmarek, L. K., and Hardwick, J. M. (2003). BAK alters neuronal excitability and can switch from anti- to pro-death function during postnatal development. Dev. Cell $4,575-585$.

Flavell, S.W., and Greenberg, M.E. (2008). Signaling mechanisms linking neuronal activity to gene expression and plasticity of the nervous system. Annu. Rev. Neurosci. 31, 563-590.

Fujikawa,D.G. (2005). Prolonged seizures and cellular injury: understanding the connection. Epilepsy Behav. 7(Suppl. 3), S3-S11.

Fujikawa, D. G., Shinmei, S. S., Zhao, S., and Aviles, E. R. Jr. (2007). Caspasedependent programmed cell death pathways are not activated in generalized seizure-induced neuronal death. Brain Res. 1135, 206-218.

Galluzzi, L., Joza, N., Tasdemir,E., Maiuri, M. C., Hengartner, M., Abrams, J. M.,
Tavernarakis, N., Penninger, J., Madeo, F., and Kroemer, G. (2008). No death without life: vital functions of apoptotic effectors. Cell Death Differ. 15, 1113-1123.

Gangarossa, G., Di Benedetto, M., O'Sullivan, G. J., Dunleavy, M., Alcacer, C., Bonito-Oliva, A., Henshall, D. C., Waddington, J. L., Valjent, E., and Fisone, G. (2011). Convulsant doses of a dopamine $\mathrm{d} 1$ receptor agonist result in erk-dependent increases in zif268 and arc/arg3.1 expression in mouse dentate gyrus. PLoS ONE 6, e19415. doi: 10.1371/journal.pone.0019415

Giorgi, F. S., Blandini, F., Cantafora, E., Biagioni, F.,Armentero, M. T., Pasquali, L., Orzi, F., Murri, L., Paparelli, A., and Fornai, F. (2008). Activation of brain metabolism and fos during limbic seizures: the role of locus coeruleus. Neurobiol. Dis. 30, 388-399.

Giorgi, F. S., Pizzanelli, C., Biagioni, F., Murri, L., and Fornai, F. (2004). The role of norepinephrine in epilepsy: from the bench to the bedside. Neurosci. Biobehav. Rev. 28, 507-524.

Greengard, P. (2001). The neurobiology of slow synaptic transmission. Science 294, 1024-1030.

Greengard, P., Allen, P. B., and Nairn, A. C. (1999). Beyond the dopamine receptor: the DARPP-32/protein phosphatase-1 cascade. Neuron 23, 435-447.

Hangen, E., Blomgren, K., Benit, P., Kroemer, G., and Modjtahedi, N. (2010). Life with or without AIF. Trends Biochem. Sci. 35, 278-287.

Hannon, J., and Hoyer, D. (2008). Molecular biology of 5-HT receptors. Behav. Brain. Res. 195, 198-213.

Henshall, D. C., Araki, T., Schindler, C. K., Lan, J. Q., Tiekoter, K. L., Taki, W., and Simon, R. P. (2002). Activation of Bcl2-associated death protein and counterresponse of Akt within cell populations during seizure-induced neuronal death. J. Neurosci. 22, 8458-8465.

Henshall, D. C., Bonislawski, D. P., Skradski, S. L., Araki, T., Lan, J. Q., Schindler, C. K., Meller, R., and Simon, R.P. (2001a). Formation of the Apaf-1/ cytochrome c complex precedes activation of caspase-9 during seizureinduced neuronal death. Cell Death Differ. 8, 1169-1181.

Henshall, D. C., Bonislawski, D. P., Skradski, S. L., Lan, J. Q., Meller, R., and Simon, R. P. (2001b). Cleavage of Bid may amplify caspase-8-induced neuronal death following focally evoked limbic seizures. Neurobiol. Dis. 8, 568-580.

Henshall, D. C., Chen, J., and Simon, R. P. (2000a). Involvement of caspase-3-like protease in the mechanism of cell death following focally evoked limbic seizures. J. Neurochem. 74, 1215-1223.
Henshall, D. C., Clark, R. S., Adelson, P.D., Chen, M., Watkins, S. C., and Simon, R. P. (2000b). Alterations in bcl-2 and caspase gene family protein expression in human temporal lobe epilepsy. Neurology 55, 250-257.

Henshall, D. C., Sinclair, J., and Simon, R. P. (1999). Relationship between seizure-induced transcription of the DNA damage-inducible gene GADD45, DNA fragmentation, and neuronal death in focally evoked limbic epilepsy. J. Neurochem. 73 , 1573-1583.

Herdegen, T., Claret, F. X., Kallunki, T., Martin-Villalba, A., Winter, C., Hunter, T., and Karin, M. (1998). Lasting N-terminal phosphorylation of c-Jun and activation of c-Jun $\mathrm{N}$-terminal kinases after neuronal injury. J. Neurosci. 18, 5124-5135.

Herdegen, T., and Leah, J. D. (1998) Inducible and constitutive transcription factors in the mammalian nervous system: control of gene expression by Jun, Fos and Krox, and CREB/ATF proteins. Brain Res. Brain Res. Rev. 28, 370-490.

Herrera, D. G., and Robertson, H. A. (1996). Activation of c-fos in the brain. Prog. Neurobiol. 50, 83-107.

Houser, C. R., Huang, C. S., and Peng, Z. (2008). Dynamic seizure-related changes in extracellular signal-regulated kinase activation in a mouse model of temporal lobe epilepsy. Neuroscience 156, 222-237.

Hughes, P. E., Alexi, T., Walton, M. Williams, C.E., Dragunow, M., Clark, R. G., and Gluckman, P. D. (1999). Activity and injury-dependent expression of inducible transcription factors, growth factors and apoptosis-related genes within the central nervous system. Prog. Neurobiol. 57, 421-450.

Inestrosa, N. C., and Arenas, E. (2010). Emerging roles of Wnts in the adult nervous system. Nat. Rev. Neurosci. $11,77-86$.

Jiao, S., and Li, Z. (2011). Nonapoptotic function of BAD and BAX in longterm depression of synaptic transmission. Neuron 70, 758-772.

Ju, K. L., Manley, N. C., and Sapolsky, R.M. (2008). Anti-apoptotic therapy with a Tat fusion protein protects against excitotoxic insults in vitro and in vivo. Exp. Neurol. 210, 602-607.

Kasof, G. M., Mandelzys, A., Maika, S. D., Hammer, R. E., Curran, T., and Morgan, J. I. (1995). Kainic acidinduced neuronal death is associated with DNA damage and a unique immediate-early gene response in c-fos-lacZ transgenic rats. J. Neurosci. $15,4238-4249$.

Kaytor, M. D., and Orr, H. T. (2002). The GSK3 beta signaling cascade and neurodegenerative disease. Curr. Opin. Neurobiol. 12, 275-278.
Kim, Y.S., Hong, K. S., Seong, Y. S., Park, J. B., Kuroda, S., Kishi, K., Kaibuchi, K., and Takai, Y. (1994). Phosphorylation and activation of mitogen-activated protein kinase by kainic acidinduced seizure in rat hippocampus. Biochem. Biophys. Res. Commun. 202, 1163-1168.

Kokaia, M. (2011). Seizure-induced neurogenesis in the adult brain. Eur. J. Neurosci. 33, 1133-1138.

Kondo, T., Sharp, F. R., Honkaniemi, J., Mikawa, S., Epstein, C. J., and Chan, P. H. (1997). DNA fragmentation and Prolonged expression of c-fos, c-jun, and hsp70 in kainic acid-induced neuronal cell death in transgenic mice overexpressing human CuZnsuperoxide dismutase. J. Cereb. Blood Flow Metab. 17, 241-256.

Konig, H. G., Rehm, M., Gudorf, D., Krajewski, S., Gross, A., Ward, M. W., and Prehn, J. H. (2007). Full length Bid is sufficient to induce apoptosis of cultured rat hippocampal neurons. BMC Cell Biol. 8, 7. doi: 10.1186/1471-2121-8-7

Korhonen, L., Belluardo, N., Mudo, G., and Lindholm, D. (2003). Increase in $\mathrm{Bcl}-2$ phosphorylation and reduced levels of BH3-only Bcl-2 family proteins in kainic acid-mediated neuronal death in the rat brain. Eur. J. Neurosci. $18,1121-1134$.

Kuroki, K., Virard, I., Concannon, C. G., Engel, T., Woods, I., Taki, W., Plesnila, N., Henshall, D. C., and Prehn, J. H. (2009). Effects of transient focal cerebral ischemia in mice deficient in puma. Neurosci. Lett. 451, 237-240.

Lamb, H. M., and Hardwick, M. (2010). Noncanonical functions of BCL-2 proteins in the nervous system. $A d v$. Exp. Med. Biol. 687, 115-129.

Lan, J., Henshall, D. C., Simon, R. P., and Chen, J. (2000). Formation of the base modification 8-hydroxyl-2'-deoxyguanosine and DNA fragmentation following seizures induced by systemic kainic acid in the rat. J. Neurochem. 74, 302-309.

Lawrence, M. S., Ho, D. Y., Sun, G. H., Steinberg, G. K., and Sapolsky, R. M. (1996). Overexpression of Bcl-2 with herpes simplex virus vectors protects CNS neurons against neurological insults in vitro and in vivo. J. Neurosci. 16, 486-496.

Li, C., Xu, B., Wang, W. W., Yu, X. J., Zhu, J., Yu, H. M., Han, D., Pei, D. S., and Zhang, G. Y. (2010a). Coactivation of GABA receptors inhibits the JNK3 apoptotic pathway via disassembly of GluR6-PSD-95-MLK3 signaling module in KA-induced seizure. Epilepsia 51,391-403.

Li, Y., Peng, Z., Xiao, B., and Houser, C. R. (2010b). Activation of ERK by spontaneous seizures in neural progenitors 
of the dentate gyrus in a mouse model of epilepsy. Exp. Neurol. 224, 133-145.

Li, Z., Jo, J., Jia, J. M., Lo, S. C., Whitcomb, D. J., Jiao, S., Cho, K., and Sheng, M. (2010c). Caspase-3 activation via mitochondria is required for longterm depression and AMPA receptor internalization. Cell 141, 859-871.

Li, T., Lu, C., Xia, Z., Xiao, B., and Luo, Y. (2006). Inhibition of caspase-8 attenuates neuronal death induced by limbic seizures in a cytochrome c-dependent and Smac/DIABLO-independent way. Brain Res. 1098, 204-211.

Lothman, E. W., and Collins, R. C. (1981). Kainic acid induced limbic seizures: metabolic, behavioral, electroencephalographic and neuropathological correlates. Brain Res. 218, 299-318.

Lothman, E. W., Collins, R. C., and Ferrendelli, J. A. (1981). Kainic acidinduced limbic seizures: electrophysiologic studies. Neurology 31, 806-812.

Mandic, A., Viktorsson, K., Strandberg, L., Heiden, T., Hansson, J., Linder, S., and Shoshan, M. C. (2002). Calpainmediated Bid cleavage and calpainindependent Bak modulation: two separate pathways in cisplatininduced apoptosis. Mol. Cell. Biol.22, 3003-3013.

Manno, I., Antonucci, F., Caleo, M., and Bozzi, Y. (2007). BoNT/E prevents seizure-induced activation of caspase 3 in the rat hippocampus. Neuroreport 18, 373-376.

McNamara, J. O., Huang, Y. Z., and Leonard, A. S. (2006). Molecular signaling mechanisms underlying epileptogenesis. Sci. STKE 2006, re12.

Meador-Woodruff, J. H., Mansour, A., Healy, D. J., Kuehn, R., Zhou, Q. Y., Bunzow, J. R., Akil, H., Civelli, O., and Watson, S. J.Jr. (1991). Comparison of the distributions of D1 and D2 dopamine receptor mRNAs in rat brain. Neuropsychopharmacology5, 231-242.

Meldrum, B. (1991). Excitotoxicity and epileptic brain damage. Epilepsy Res. 10, 55-61.

Mielke, K., Brecht, S., Dorst, A., and Herdegen, T. (1999). Activity and expression of JNK1, p38 and ERK kinases, c-Jun N-terminal phosphorylation, and c-jun promoter binding in the adult rat brain following kainate-induced seizures. Neuroscience 91, 471-483.

Missale, C., Nash, S. R., Robinson, S. W., Jaber, M., and Caron, M. G. (1998). Dopamine receptors: from structure to function. Physiol. Rev. 78, 189-225.

Morgan, J. I., Cohen, D. R., Hempstead, J. L., and Curran, T. (1987). Mapping patterns of $\mathrm{c}$-fos expression in the central nervous system after seizure. Science 237, 192-197.

Morgan, J. I., and Curran, T. (1989). Stimulus-transcription cou- pling in neurons: role of cellular immediate-early genes. Trends Neurosci. 12, 459-462.

Morgan, J. I., and Curran, T. (1991a). Proto-oncogene transcription factors and epilepsy. Trends Pharmacol. Sci. $12,343-349$.

Morgan, J. I., and Curran, T. (1991b). Stimulus-transcription coupling in the nervous system: involvement of the inducible proto-oncogenes fos and jun. Annu. Rev. Neurosci. 14, 421-451.

Murphy, B., Dunleavy, M., Shinoda, S., Schindler, C., Meller, R., BellverEstelles, C., Hatazaki, S., Dicker, P., Yamamoto, A., Koegel, I., Chu, X., Wang, W., Xiong, Z., Prehn, J., Simon, R., and Henshall, D. (2007). $\mathrm{Bcl}-\mathrm{w}$ protects hippocampus during experimental status epilepticus. Am. J. Pathol. 171, 1258-1268.

Murphy, B. M., Engel, T., Paucard, A., Hatazaki, S., Mouri, G., Tanaka, K., Tuffy, L. P., Jimenez-Mateos, E. M., Woods, I., Dunleavy, M., Bonner, H. P., Meller, R., Simon, R. P., Strasser, A., Prehn, J. H., and Henshall, D. C. (2010). Contrasting patterns of Bim induction and neuroprotection in Bim-deficient mice between hippocampus and neocortex after status epilepticus. Cell Death Differ. 17, 459-468.

Narkilahti, S., Jutila, L., Alafuzoff, I., Karkola, K., Paljarvi, L., Immonen, A., Vapalahti,M.,Mervaala,E., Kalviainen, R., and Pitkanen, A. (2007). Increased expression of caspase 2 in experimental and human temporal lobe epilepsy. Neuromol. Med. 9, 129-144.

Narkilahti, S., Nissinen, J., and Pitkanen, A. (2003a). Administration of caspase 3 inhibitor during and after status epilepticus in rat: effect on neuronal damage and epileptogenesis. Neuropharmacology 44, 1068-1088.

Narkilahti, S., Pirttila, T. J., Lukasiuk, K., Tuunanen, J., and Pitkanen, A. (2003b). Expression and activation of caspase 3 following status epilepticus in the rat. Eur. J. Neurosci. 18, 1486-1496.

Narkilahti, S., and Pitkanen, A. (2005). Caspase 6 expression in the rat hippocampus during epileptogenesis and epilepsy. Neuroscience 131, 887-897.

Nishi, A., Snyder, G. L., and Greengard, P. (1997). Bidirectional regulation of DARPP-32 phosphorylation by dopamine. J. Neurosci. 17, 8147-8155.

Noh, H. S., Kim, Y. S., Kim, Y. H., Han, J. Y., Park, C. H., Kang, A. K., Shin, H. S., Kang, S. S., Cho, G. J., and Choi, W. S. (2006). Ketogenic diet protects the hippocampus from kainic acid toxicity by inhibiting the dissociation of bad from 14-3-3. J. Neurosci. Res. 84, 1829-1836.
Okamoto, O. K., Janjoppi, L., Bonone, F. M., Pansani, A. P., Da Silva, A. V., Scorza, F. A., and Cavalheiro, E. A. (2010). Whole transcriptome analysis of the hippocampus: toward a molecular portrait of epileptogenesis. BMC Genomics 11, 230. doi: 10.1186/1471-2164-11-230

Orrenius, S., Zhivotovsky, B., and Nicotera, P. (2003). Regulation of cell death: the calcium-apoptosis link. Nat. Rev. Mol. Cell Biol. 4, 552-565.

O'Sullivan, G. J., Dunleavy, M., Hakansson, K., Clementi, M., Kinsella, A., Croke, D. T., Drago, J., Fienberg, A. A., Greengard, P., Sibley, D. R., Fisone, G., Henshall, D. C., and Waddington, J. L. (2008). Dopamine D1 vs D5 receptor-dependent induction of seizures in relation to DARPP-32, ERK1/2 and GluR1-AMPA signalling. Neuropharmacology 54, 1051-1061.

O'Sullivan, G. J., Kinsella, A., Sibley, D. R., Tighe, O., Croke,D.T., and Waddington, J. L. (2005). Ethological resolution of behavioural topography and D1-like versus D2-like agonist responses in congenic D5 dopamine receptor mutants: identification of D5:D2-like interactions. Synapse 55, 201-211.

Pei, Q., Tordera, R., Sprakes, M., and Sharp, T. (2004). Glutamate receptor activation is involved in 5-HT2 agonist-induced Arc gene expression in the rat cortex. Neuropharmacology 46, 331-339.

Perez, R. G., and Lewis, R. M. (1992). Regional distribution of DARPP32 (dopamine- and adenosine $3^{\prime}, 5^{\prime}$-monophosphate-regulated phosphoprotein of $\mathrm{Mr}=32,000)$ mRNA in mouse brain. J. Comp. Neurol. 318, 304-315.

Pitkänen, A., Schwartzkroin, P., and Moshé, S. (2005). Models of Seizures and Epilepsy. Burlington, MA: Elsevier Academic Press.

Pitkanen, A., and Sutula, T. P. (2002). Is epilepsy a progressive disorder? Prospects for new therapeutic approaches in temporal-lobe epilepsy. Lancet Neurol. 1, 173-181.

Plesnila, N., Zinkel, S., Le, D. A., AminHanjani, S., Wu, Y., Qiu, J., Chiarugi, A., Thomas, S. S., Kohane, D. S., Korsmeyer, S. J., and Moskowitz, M. A. (2001). BID mediates neuronal cell death after oxygen/glucose deprivation and focal cerebral ischemia. Proc. Natl. Acad. Sci. U.S.A. 98, 15318-15323.

Puthalakath, H., O'reilly, L. A., Gunn, P., Lee, L., Kelly, P. N., Huntington, N. D., Hughes, P. D., Michalak, E. M., Mckimm-Breschkin, J., Motoyama, N., Gotoh, T., Akira, S., Bouillet, P., and Strasser, A. (2007). ER stress triggers apoptosis by activating $\mathrm{BH} 3$-only protein Bim. Cell 129, 1337-1349.
Racine, R.J.(1972).Modification of seizure activity by electrical stimulation. II. Motor seizure. Electroencephalogr. Clin. Neuroeurophysiol. 32, 281-294.

Raivich, G., and Behrens, A. (2006). Role of the AP-1 transcription factor c-Jun in developing, adult and injured brain. Prog. Neurobiol. 78, 347-363.

Sarnyai, Z., Sibille, E. L., Pavlides, C., Fenster, R. J., McEwen, B. S., and Toth, M. (2000). Impaired hippocampaldependent learning and functional abnormalities in the hippocampus in mice lacking serotonin(1A) receptors. Proc. Natl. Acad. Sci. U.S.A. 97, 14731-14736.

Savinainen, A., Garcia, E. P., Dorow, D., Marshall, J., and Liu, Y. F. (2001) Kainate receptor activation induces mixed lineage kinase-mediated cellular signaling cascades via post-synaptic density protein 95. J. Biol. Chem. 276, 11382-11386.

Schauwecker, P. E. (2000). Seizureinduced neuronal death is associated with induction of c-Jun N-terminal kinase and is dependent on genetic background. Brain Res. 884, 116-128. Sedarous, M., Keramaris, E., O'hare, M., Melloni, E., Slack, R. S., Elce, J. S., Greer, P. A., and Park, D. S. (2003). Calpains mediate p53 activation and neuronal death evoked by DNA damage. J. Biol. Chem. 278, 26031-26038.

Sheng, M., and Greenberg, M. E. (1990). The regulation and function of $\mathrm{c}-\mathrm{fos}$ and other immediate early genes in the nervous system. Neuron 4, 477-485.

Shinoda, S., Schindler, C. K., Meller, R., So, N. K., Araki, T., Yamamoto, A., Lan, J. Q., Taki, W., Simon, R. P., and Henshall, D. C. (2004). Bim regulation may determine hippocampal vulnerability after injurious seizures and in temporal lobe epilepsy. J. Clin. Invest. 113, 1059-1068.

Shinoda, S., Skradski, S. L., Araki, T., Schindler, C. K., Meller, R., Lan, J. Q., Taki, W., Simon, R. P., and Henshall, D. C. (2003). Formation of a tumour necrosis factor receptor 1 molecular scaffolding complex and activation of apoptosis signal-regulating kinase 1 during seizure-induced neuronal death. Eur. J. Neurosci. 17, 2065-2076.

Simonato, M., Tongiorgi, E., and Kokaia, M. (2006). Angels and demons: neurotrophic factors and epilepsy. Trends Pharmacol. Sci. 27, 631-638.

Smeyne, R. J., Schilling, K., Robertson, L., Luk, D., Oberdick, J., Curran, T., and Morgan, J. I. (1992). fos-lacZ transgenic mice: mapping sites of gene induction in the central nervous system. Neuron 8, 13-23.

Smeyne, R. J., Vendrell, M., Hayward, M., Baker, S. J., Miao, G. G., Schilling, K., Robertson, L. M., Curran, T., and Morgan, J. I. (1993). Continuous c-fos 
expression precedes programmed cell death in vivo. Nature 363, 166-169.

Spigolon, G., Veronesi, C., Bonny, C., and Vercelli, A. (2010). c-Jun N-terminal kinase signaling pathway in excitotoxic cell death following kainic acid-induced status epilepticus. Eur. J. Neurosci. 31, 1261-1272.

Starr, M. S. (1993). "Regulation of seizure threshold by D1 versus D2 receptors," in D1/D2 Dopamine Receptor Interactions, ed. J. Waddington (New York: Academic Press), 235-269.

Starr, M. S. (1996). The role of dopamine in epilepsy. Synapse 22, 159-194.

Starr, M. S., and Starr, B. S. (1993). Seizure promotion by $\mathrm{D} 1$ agonists does not correlate with other dopaminergic properties. J. Neural Transm. Park. Dis. Dement. Sect. 6, 27-34.

Stellwagen, D., and Malenka, R. C. (2006). Synaptic scaling mediated by glial TNF-alpha. Nature 440, 1054-1059.

Susin, S. A., Lorenzo, H. K., Zamzami, N., Marzo, I., Snow, B. E., Brothers, G. M., Mangion, J., Jacotot, E., Costantini, P., Loeffler, M., Larochette, N., Goodlett, D. R., Aebersold, R., Siderovski, D. P., Penninger, J. M., and Kroemer, G. (1999). Molecular characterization of mitochondrial apoptosis-inducing factor. Nature 397, 441-446.

Svenningsson, P., Tzavara, E. T., Liu, F., Fienberg, A. A., Nomikos, G. G., and Greengard, P. (2002). DARPP-32 mediates serotonergic neurotransmission in the forebrain. Proc. Natl. Acad. Sci. U.S.A. 99, 3188-3193.

Takano, J., Tomioka, M., Tsubuki, S., Higuchi, M., Iwata, N., Itohara, S., Maki, M., and Saido, T. C. (2005). Calpain mediates excitotoxic DNA fragmentation via mitochondrial pathways in adult brains: evidence from calpastatin mutant mice. J. Biol. Chem. 280, 16175-16184.

Tecott, L. H., Sun, L. M., Akana, S. F., Strack, A. M., Lowenstein, D. H., Dallman, M. F., and Julius, D. (1995). Eating disorder and epilepsy in mice lacking 5-HT2c serotonin receptors. Nature 374, 542-546.

Theofilas, P., Bedner, P., Huttmann, K., Theis, M., Steinhauser, C., and Frank, S. (2009). The proapoptotic BCL-2 homology domain 3-only protein Bim is not critical for acute excitotoxic cell death. J. Neuropathol. Exp. Neurol.68, 102-110.

Thornton, T. M., Pedraza-Alva, G., Deng, B., Wood, C. D., Aronshtam, A., Clements, J. L., Sabio, G., Davis, R. J., Matthews, D. E., Doble, B., and Rincon, M. (2008). Phosphorylation by $\mathrm{p} 38 \mathrm{MAPK}$ as an alternative pathway for GSK3beta inactivation. Science 320, 667-670.

Tongiorgi, E., Armellin, M., Giulianini, P. G., Bregola, G., Zucchini, S., Paradiso, B., Steward, O., Cattaneo, A., and Simonato, M. (2004). Brain-derived neurotrophic factor mRNA and protein are targeted to discrete dendritic laminas by events that trigger epileptogenesis. J. Neurosci. 24, 6842-6852.

Tripathi, P. P., Di Giovannantonio, L. G., Viegi, A., Wurst, W., Simeone, A., and Bozzi, Y. (2008). Serotonin hyperinnervation abolishes seizure susceptibility in Otx2 conditional mutant mice. J. Neurosci. 28, 9271-9276.

Tripathi, P. P., Santorufo, G., Brilli, E., Borrelli, E., and Bozzi, Y. (2010). Kainic acid-induced seizures activate GSK3beta in the hippocampus of D2R-/mice. Neuroreport 21, 846-850.

Turski, L., Ikonomidou, C., Turski, W. A., Bortolotto, Z. A., and Cavalheiro, E. A. (1989). Review: cholinergic mechanisms and epileptogenesis. The seizures induced by pilocarpine: a novel experimental model of intractable epilepsy. Synapse 3, 154-171.

Vezzani, A., Balosso, S., Maroso, M., Zardoni, D., Noe, F., and Ravizza, T. (2010). ICE/caspase 1 inhibitors and IL-1beta receptor antagonists as potential therapeutics in epilepsy. Curr. Opin. Investig. Drugs 11, 43-50. Viswanath, V., Wu, Z., Fonck, C., Wei, Q., Boonplueang, R., and Andersen, J. K. (2000). Transgenic mice neuronally expressing baculoviral $\mathrm{p} 35$ are resistant to diverse types of induced apoptosis, including seizure-associated neurodegeneration. Proc. Natl. Acad. Sci. U.S.A. 97, 2270-2275.

Vosler, P. S., Brennan, C. S., and Chen, J. (2008). Calpain-mediated signaling mechanisms in neuronal injury and neurodegeneration. Mol. Neurobiol. $38,78-100$.

Wang, S., Wang, S., Shan, P., Song, Z., Dai, T., Wang, R., and Chi, Z. (2008).
Mu-calpain mediates hippocampal neuron death in rats after lithiumpilocarpine-induced status epilepticus. Brain Res. Bull. 76, 90-96.

Watanabe, Y., Johnson, R. S., Butler, L. S., Binder, D. K., Spiegelman, B. M., Papaioannou, V. E., and McNamara, J. O. (1996). Null mutation of c-fos impairs structural and functional plasticities in the kindling model of epilepsy. J. Neurosci. 16, 3827-3836.

Weinshenker, D., and Szot, P. (2002). The role of catecholamines in seizure susceptibility: new results using genetically engineered mice. Pharmacol. Ther. 94, 213-233.

Weise, J., Engelhorn, T., Dorfler, A., Aker, S., Bahr, M., and Hufnagel, A. (2005). Expression time course and spatial distribution of activated caspase- 3 after experimental status epilepticus: Contribution of delayed neuronal cell death to seizure-induced neuronal injury. Neurobiol. Dis. 18, 582-590.

West, A. E., Griffith, E. C., and Greenberg, M.E. (2002). Regulation of transcription factors by neuronal activity. Nat. Rev. Neurosci. 3, 921-931.

Willoughby, J. O., Mackenzie, L., Medvedev, A., and Hiscock, J. J. (1997). Fos induction following systemic kainic acid: early expression in hippocampus and later widespread expression correlated with seizure. Neuroscience 77, 379-392.

Wilson, N. S., Dixit, V., and Ashkenazi, A. (2009). Death receptor signal transducers: nodes of coordination in immune signaling networks. Nat. Immunol. 10, 348-355.

Xiang, H., Kinoshita, Y., Knudson, C. M., Korsmeyer, S. J., Schwartzkroin, P. A., and Morrison, R. S. (1998). Bax involvement in p53-mediated neuronal cell death. J. Neurosci. 18, 1363-1373.

Xu, C., Bailly-Maitre, B., and Reed, J. C. (2005). Endoplasmic reticulum stress: cell life and death decisions. J. Clin. Invest. 115, 2656-2664.

Yang, D. D., Kuan, C. Y., Whitmarsh, A. J., Rincon, M., Zheng, T. S., Davis, R. J., Rakic, P., and Flavell, R. A. (1997). Absence of excitotoxicity-induced apoptosis in the hippocampus of mice lacking the Jnk3 gene. Nature $389,865-870$.
Yang, Q., Kim, Y. S., Lin, Y., Lewis, J., Neckers, L., and Liu, Z. G. (2006). Tumour necrosis factor receptor 1 mediates endoplasmic reticulum stress-induced activation of the MAP kinase JNK. EMBO Rep. 7, 622-627.

Youle, R. J., and Karbowski, M. (2005). Mitochondrial fission in apoptosis. Nat. Rev. Mol. Cell Biol. 6, 657-663.

Youle, R. J., and Strasser, A. (2008). The BCL-2 protein family: opposing activities that mediate cell death. Nat. Rev. Mol. Cell Biol. 9, 47-59.

Yuan, J., and Yankner, B. A. (2000). Apoptosis in the nervous system. Nature 407, 802-809.

Zhang, J., Yan, H., Wu, Y. P., Li, C., and Zhang, G. Y. (2011). Activation of GluR6-containing kainate receptors induces ubiquitin-dependent $\mathrm{Bcl}-2$ degradation via denitrosylation in the rat hippocampus after kainate treatment. J. Biol. Chem. 286, 7669-7680.

Zhang, J., Zhang, D., Mcquade, J. S., Behbehani, M., Tsien, J. Z., and Xu, M. (2002). c-fos regulates neuronal excitability and survival. Nat. Genet. 30, 416-420.

Zhao, S., Aviles, E. R. Jr., and Fujikawa, D. G. (2010). Nuclear translocation of mitochondrial cytochrome $\mathrm{c}$, lysosomal cathepsins B and D, and three other death-promoting proteins within the first 60 minutes of generalized seizures. J. Neurosci. Res. 88, 1727-1737.

Conflict of Interest Statement: The authors declare that the research was conducted in the absence of any commercial or financial relationships that could be construed as a potential conflict of interest.

Received: 08 June 2011; accepted: 13 July 2011; published online: 02 August 2011. Citation: Bozzi Y, Dunleavy Mand Henshall DC (2011) Cell signaling underlying epileptic behavior. Front. Behav. Neurosci. 5:45. doi: 10.3389/fnbeh.2011.00045

Copyright (๑ 2011 Bozzi, Dunleavy and Henshall. This is an open-access article subject to a non-exclusive license between the authors and Frontiers Media SA, which permits use, distribution and reproduction in other forums, provided the original authors and source are credited and other Frontiers conditions are complied with. 